\title{
Thèse et antithèse: le Conseil des universités et les universités québécoises face à l'éducation permanente
}

\author{
PIERRE GINGRAS* \\ JOHN P. LIPKIN**
}

Si nous devions juger les systèmes d'enseignement universitaire des sociétés industrielles avançées uniquement d'après leurs effectifs étudiants, il n'y aurait que peu de raisons de parler de crise de l'enseignement supérieur; en effet, les efforts de tous ordres consentis par les universités depuis les années 1960 ont produit un taux de scolarisation du groupe d'âge concerné de plus de 1,000 étudiants par 100,000 habitants.

En dépit de ces efforts le système universitaire, à l'échelle mondiale tout comme au Québec, traverse une crise d'identité inhérente aux réalités sociales et politiques modernes. L'université, fractionnée quant à la nature, à l'objet et au champ de ses activités, présente une disproportion entre la vigueur des influences extérieures et ses forces internes. Cette crise se ressent avec d'autant plus d'acuité que la démocratisation de l'enseignement en a décuplé les effets. Elle survient, de plus, au moment où l'on propose un changement fondamental de toute la pensée éducative du monde moderne, soit le concept d'éducation permanente.(1) Ce dernier, devant inspirer l'évolution des systèmes d'enseignement et en être le principe directeur est endossé par le Conseil des universités de la Province de Québec. A la recommandation 1 de son rapport, il est affirmé:

"Que soit choisi comme principe de l'ensemble de notre système d'éducation et en particulier de l'enseignement supérieur, le principe de l'éducation permanente". (2)

Nous dégagerons dans un premier temps la notion d'éducation permanente telle que recommandée par le Conseil. Nous analyserons ensuite la réponse des universités québécoises. Nous nous intéresserons enfin aux répercussions et aux changements radicaux auxquels donnerait lieu, pour les universités, l'adoption de cette recommandation.

\section{L'éducation permanente et le Conseil des universités}

Bien que le Conseil des universités recommande que l'éducation permanente soit le principe directeur du système d'éducation, tant s'en faut que cette recommandation ne de-

\footnotetext{
* Pierre Gingras, Etudiant aux Grades Supérieurs, Université de Montréal

** John P. Lipkin, Associate Professor of Education, McGill University
} 
vienne le cadre opérationnel du développement universitaire. En effet, "la loi du Conseil des universités" lui reconnait comme fonction principale "de donner des avis au ministre de l'éducation sur les besoins de l'enseignement supérieur et de la recherche universitaire et de lui faire des recommandations sur les mesures à prendre pour combler ces besoins". (3) Malgré son caractère consultatif auprès du ministre, d'une part, et l'autonomie complète des universités, d'autre part, il n'en demeure pas moins que le Conseil devrait devenir une force motrice de la réforme de l'enseignement universitaire québécois.

Pour le Conseil, l'éducation permanente désigne un processus global d'éducation, où le fractionnement de la vie en une période pour apprendre et l'autre pour vivre ne répond plus à l'accélération du changement technologique du monde moderne.(4) Toutes ces transformations comportent une conséquence évidente: non seulement les systèmes d'enseignement doivent changer d'objectif et cesser de maintenir une équivalence entre le diplôme et la fin des études, mais ils doivent dorénavant former des individus capables d'apprendre et de s'adapter tout au long de leur vie à un environnement toujours mouvant. Il faut donc faire appel à une conception revisée de la durée des études, de leur contenu et surtout, à une révision de la demande sociale d'éducation.

Il convient aussi de distinguer entre "éducation permanente" et "éducation des adultes". $\mathrm{Au}$ niveau universitaire, l'éducation permanente comprendrait toutes les activités d'enseignement régulier, de recyclage, de perfectionnement et de services périuniversitaires alors que sous l'étiquette "éducation des adultes" seraient regroupées les seules activités de recyclage, de perfectionnement et de services périuniversitaires.(5) L'application du concept d'éducation permanente imposerait l'intégration de tous les enseignements, c'està-dire l'abolition des distinctions entre enseignement régulier de jour, et enseignement du soir, du samedi ou d'été. C'est dire que l'université ne serait plus exclusivement conçue pour les étudiants réguliers à plein temps mais devrait accueillir des étudiants réguliers à temps partiel, tout comme des étudiants à temps partiel ne postulant pas de diplôme, mais inscrits à des programmes de rattrapage, de recyclage ou de perfectionnement.(6) Et le Conseil d'affirmer:

"Il s'ensuit que devraient être éventuellement abolis tous les services dits d'éducation permanente, d'extension, de cours d'été, de cours du samedi ou du soir. Tels qu'ils existent présentement, les enseignements que ces services organisent devront tous, un jour, être organisés comme des enseignements réguliers, et en avoir toutes les caractéristiques; leur encadrement sera rapatrié par les facultés, les départements ou les modules qui peuvent, au même titre que les services administratifs spécifiques actuels, identifier les besoins du milieu et assurer la coordination des enseignements". (7)

Seuls les services populaires, c'est-à-dire ceux constitués de cours ou d'activités de niveau universitaire ou pré-universitaire ne donnant aucun crédit devront faire l'objet de distinctions particulières. Ces cours, formant un ensemble anarchique d'activités non scolaires d'éducation et de formation, sont un important complément de l'enseignement scolaire formel, et il est surprenant de constater que le Conseil n'intègre pas ces activités aux formules actuelles de financement.

Le Conseil tempère cependant le caractère révolutionnaire de ses recommandations, soit par doute méthodique puisque les résultats de l'étude qu'il a commandé conjointe- 
ment avec la Conférence des recteurs ne sont pas encore déposés,(8) soit par réalisme car il constate que les universités sont inégalement préparées à l'application de ce concept; il ajoute aussi que le caractère intégrateur de l'éducation permanente est encore insuffisam. ment perçu et que les conséquences pratiques n'ont guère été l'objet d'analyse. Il s'agit, en attendant, d'accorder à l'éducation des adultes, une des composantes de l'éducation permanente, une attention et un effort accrus.(9) Mais avons-nous des indices pour croire que les universités soient disposées à de telles mutations? Peuvent-elles remettre en cause la nature et les finalités de leur existence? Où et comment percevoir des éléments de réponse?

\section{La réponse des universités}

En soi, il est difficile de connaître et de mesurer la réaction des universités à cause de l'absence de prises de position sur l'objet de l'éducation permanente, prises de position qui pour plusieurs apparaissent prématurées. Le recteur de l'Université Laval(10) avouait d'ailleurs que tous les efforts et toutes les énergies intellectuelles n'avaient pas encore été mobilisées au profit de l'éducation des adultes. Pourrions-nous croire que cet aveu est une réponse partielle au défi proposé par le Conseil des universités? Quel serait l'instrument objectif pour confirmer ou infirmer cette hypothèse?

Les grandes orientations, ou "axes de développement", définis dans le rapport par chacune des universités pourraient fournir un certain élément de réponse; par axe de développement, il faut entendre non point les activités du niveau départemental ou du module, mais celles caractérisant une institution universitaire soit par un champ de connaissances, soit par une méthode de diffusion du savoir, soit par un type particulier de clientèle scolaire. (11)

Deux universités, et ce pour des raisons historiques ou idéologiques, assument le concept d'éducation permanente; ce sont respectivement l'Université Sir George Williams et l'Université du Québec. L'Université Sir George poursuit ainsi son axe traditionnel orienté vers la satisfaction des besoins du milieu, et dont la majorité des étudiants sont inscrits à des programmes de premier cycle à temps partiel.(12) Par ailleurs, dès sa création, l'Université du Québec se proposait d'être un agent de changement socio-économique et culturel en plus d'être un lieu de formation personnelle, d'éducation permanente et de recherche. (13) C'est pourquoi les étudiants à temps partiel continueront de représenter $40 \%$ de ses activités d'enseignement et de constituer $60 \%$ de sa population étudiante. En outre, elle veut continuer d'intensifier son effort d'éducation permanente par l'accroissement de l'accessibilité de ses services aux adultes et par le développement d'une "télé-université" afin de rejoindre les populations les plus éloignées et les plus dispersées.(14) Quant à l'Université de Montréal, les recommandations d'un comité "ad hoc" font qu'elle apportera d'importants changements à son service d'éducation permanente qui modifieront sa réceptivité à l'éducation permanente, en intégrant la formation des adultes à la vie de l'université, en rendant accessible pour les étudiants à temps partiel tous les enseignements dans tous les secteurs et à tous les niveaux, et en créant des programmes spéciaux qui satisfassent aux besoins particuliers des adultes. (15)

Pour ce qui est des autres universités, elles sont à des stades différents du concept d'éducation permanente. L'Université Bishop se préoccupe particulièrement d'activités de recyclage,(16) l'Université McGill commence à peine à se sensibiliser à de nouvelles respon- 
sabilités vis-à-vis l'éducation permanente(17) et les universités de Sherbrooke et Laval continuent de définir leurs activités d'éducation des adultes et d'en préciser les structures d'encadrement.(18) Cette résistance de la majorité des universités québécoises à évoluer vers l'éducation permanente doit certes s'expliquer par des raisons autres que des formules administratives ou financières.

Dans son ouvrage sur les stades que doit franchir l'éducation permanente,(19) le Dr Jiri Kotasek affirme que l'on ne peut parvenir à concevoir l'éducation permanente comme principe d'intégration éducative sans avoir consenti à un lent cheminement conceptuel. Au premier stade, on perçoit une différence essentielle et une contradiction entre l'éducation des enfants et celle des adultes, sans que l'idée de continuité entre les deux soit présente. Au deuxième stade, il n'existe plus de barrières infranchissables entre les deux bien que les conceptions traditionnelles, à savoir que l'école demeure une préparation à la vie et l'éducation des adultes un complément à cette préparation, ne soient pas radicalement modifiées.

Nous constatons que la majorité des universités québécoises en sont encore au premier stade, c'est-à-dire continuent de considérer les activités dites d'éducation permanente comme non-régulières, et même, marginales. Elles démontrent cette résistance au changement puisque les transformations qu'elles devront opérer, suite à la recommandation du Conseil des universités, affectent leur rôle traditionnel et leurs rapports avec l'ensemble des conditions modernes de la société.

\section{Retrospect - The Social Purpose of the University}

The Conseil's advocacy of l'éducation permanente as the organizing principle for higher education could become a significant landmark in the development of Quebec education and society, if it leads to a commitment on the part of the Government to provide appropriate educational experiences for all citizens throughout their lifetime. However, in order for this goal to come to fruition, a radical departure from the present system of education must be undertaken.

In an effort to comprehend the role of the university vis-à-vis l'éducation permanente, the salient characteristics of the educational system as it has evolved to the present day should first be noted. Historically, the university has stood at the apex of the pyramidal educational structure. In this position it has exercised a strong, if not explicit, control over the form and content of education carried out at the lower levels. The effect of this control has been to relegate to an inferior status all forms of education which do not lead to or result in a university degree. Furthermore, although the university was undoubtedly subject to the influence of the elite elements of the society, $(20)$ it remained relatively free from the pressures and constraints of the broader society and the government.

Thus, the university was able to develop and preserve those quintessential hallmarks of the pursuit of higher learning: autonomy or academic freedom and academic standards. As the fount of knowledge and wisdom, the university was seen as the guardian of the society's most cherished values and the training ground for its future leaders. Although only a relatively few gained entrance to its hallowed halls, the entire civilization was the beneficiary as the graduates went forward into the world to serve mankind, or so the prevailing belief held.

Two major, interrelated contemporary trends of modern society can be identified 
which have had the effect of challenging the autonomy and the exclusivity of the university. The first is the increased role of the government, particularly in the realm of social welfare. This has resulted in the assumption of increased governmental controls over all levels and types of education (including the university), deemed essential to societal wellbeing. The second trend is the advent of mass culture which has resulted in an inexorable increase in the social demand for access to higher education.

In effect, l'éducation permanente represents a plan of the government to extend the benefits of education for all beyond the secondary level. Therefore, it quite naturally is perceived by at least some elements of the university as a threat to its autonomy and standards. There is little evidence to suggest that the official reaction of Quebec universities will differ from the experience in Ontario where the Commission of the Relations between Universities and Government has observed that, "in fact the voluntary cooperation of universities has seldom been 'voluntary' or even 'cooperative"'.(21) As we have previously noted, this is particularly true in the case of the older, more prestigious universities; Laval, McGill, Sherbrooke and the University of Montreal; whereas the newer and more community oriented universities, the University of Quebec and Sir George Williams University, show signs of being more receptive to l'éducation permanente.

Before the university can contribute to the creation of a just and efficacious educational system, it must come to a clearer understanding of its particular role in today's society. Scientific research has led to technological developments, and the social scientist has contributed to an understanding of the complex process of social change. Yet the response of the university qua university to the contemporary social conditions, which it has helped to produce, could best be termed conservative. Indeed, as the economists' research makes increasingly clear, the university's function with respect to the central problem of the modern economy-unequal development,(22) is to generate greater inequalities through the provision of disproportionate benefits to the middle class at the expense of the poor. (23)

An examination of the university professors' research activities and publications, reveals a heightened social awareness and an increased concern for the consequences of their activities, whether they be members of science, arts or professional faculties. In fact, the rationale for l'éducation permanente borrows heavily from their collective intelligence. Such a system would result in a more equitable distribution of the state's wealth and the amelioration of conditions of life for the poor in particular, through the provision of lifelong learning opportunities for all. (24)

The problem and the solution lie in translating the knowledge and ideals of the university into practise. This cannot be accomplished by a retreat from or reaction against the pressures of the government or the populous, for as Alvin Gouldner has aptly remarked, "... the world outside the university will not leave it alone and ... the world inside the university does not want to be left alone". (25)

It remains for the university to act on the recognition that it is part of a total social system in which pedagogical functions are not restricted to educational institutions nor can they be restricted to the young and relatively privileged. In order for the university to contribute to a new system of education which has as its purpose the continual, maximum development of society's human potential,(26) it must actively seek the means to attain l'éducation permanente in concert with all elements of the society. 


\section{Notes}

1 U.N.E.S.C.O. Apprendre à être, vers une cité éducative, Rapport Faure, Collection "Le monde sans frontières", Paris, Fayard-UNESCO, 1972.

2 Conseil des universités, Objectifs généraux de l'enseignement supérieur et grandes orientations des établissements, cahier II, objectifs généraux de l'enseignement supérieur, Québec, Conseil des universités, le 22 février 1973, page 5.

3 Loi du Conseil des universités, 1968 c. 64, sanctionnée le 18 décembre 1968, article 2, dans "Recueil des lois de l'éducation, codification administrative", Québec, Gouvernement du Québec, 1970, page 273.

4 Conseil des universités, Cahier $I I$, op. cit., page 4.

5 Conseil des universités, Cahier $I I$, op. cit., page 5.

6 Conseil des universités, Cahier II, op. cit., pages 12-13.

7 Conseil des universités, Objectifs généraux de l'enseignement supérieur et grandes orientations des établissements, cahier III, première et deuxième parties, les orientations de l'enseignement supérieur dans les années 70, Québec, Conseil des universités, le 23 février 1973, page 84.

8 Etude préparée par Messieurs Gaëtan Daoust et Paul Bélanger, intitulée L'université dans une société éducative; de l'éducation des adultes à l'éducation permanente, sous la commandite du Conseil des universités et de la Conférence des recteurs et principaux des universités đu Québec, et devant être publiée aux Presses de l'Université de Montréal.

9 Conseil des universités, Cahier $I I I$, op. cit., page 85.

10 Entrevue télévisée à l'émission "Actualités 24", le 7 janvier 1974.

11 Conseil des universités, Objectifs généraux de l'enseignement supérieur et grandes orientations des établissements, cahier I, l'évolution récente de l'enseignement supérieur au Québec, Québec, Conseil des universités, le 15 juillet 1972, page 9.

12 Conseil des universités, Cahier I, op. cit., pages 238 et 253.

13 Unjversité du Québec, Premiers éléments d'une politique de développement pour l'Université du Québec, documerit de travail, Québec, Université du Québec, juin 1971, page 19.

14 Conseil des universités, Cahier I, op. cit., page 199.

15 Conseil des universités, Cahier I, op. cit., page 156.

16 Conseil des universités, Cahier I, op. cit., page 223.

17 Conseil des universités, Cahier III, op. cit., page 250.

18 Conseil des universités, Cahier I, op. cit., pages 143 et 188.

19 Kotasek, Jiri Dr, L'idée d'éducation permanente dans la réforme actuelle des systèmes éducatifs et la formation des maitres, dans "L'école et l'éducation permanente, quatre études", Paris, UNESCO, 1972 .

20 Léon Dion, "The New Social Context of the University", The University and Society, Montréal: McGill University, 1972 , page 69.

21 Quoted in, The Learning Society; Report of the Commission on Post-Secondary Education in Ontario, Toronto: Ministry of Government Services, 1972, pages 117-118.

22 John Kenneth Galbraith, Economics and the Public Purpose, Boston: Houghton Mifflin Company, 1973 , page 276.

23 Robert J. Staaf and Gordon Tullock, "Education and Equality", The Annals of the American Academy of Political and Socail Science, September 1973, pages 125-134.

24 For a succinct summary of the general purposes and a description of a system of l'éducation permanente see, J.R. Gass, "Recurrent Education-A Solution to the Crisis of Education?", The O.E.C.D. Observer, No. 64, June 1973, pages 4-7.

25 Alvin W. Gouldner, The Coming Crisis of Western Sociology, New York: Avon Books, 1970, page 512 .

26 For a more complete account or definition of l'éducation permanente see, Recurrent Education: A Strategy for Lifelong Learning, Paris: O.E.C.D., 1973. 